\title{
Protein synthesis and growth in the gastrointestinal tract of the young preruminant lamb
}

\author{
BY D. ATTAIX AND M. ARNAL \\ INRA et CNRS U.A.041163, Centre de Recherches Zootechniques et Vétérinaires de \\ Theix, 63122 Ceyrat, France
}

(Received 19 September 1986 -- Accepted 6 March 1987)

1. In Expt 1, fractional synthesis rates (FSR) of tissue protein werc measured along the gastrointestinal tract (GIT) of six l-week-old, milk-fed lambs by using a large amount of $\mathrm{L}-\left[3,4(n)-{ }^{3} \mathrm{H}\right]$ valine.

2. In Expt 2, eighteen lambs were used to determine the fractional growth rate (FGR) of gastrointestinal tissue protein

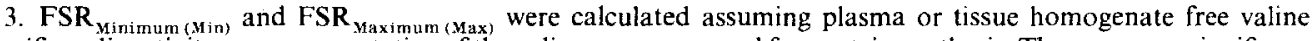
specific radioactivity was representative of the valine precursor pool for protein synthesis. There were no significant differences between FSR $_{\text {Min }}$ and FSR Max $_{\text {in }}$ in any gastrointestinal tissue of lambs used in Expt I $(P>0.05)$. FSR gradually and significantly $(P<0.05)$ increased from the oesophagus (FSR Max $_{26} 2 \%$ \%), reticulo-rumen $(30.1 \% / \mathrm{d})$, omasum $(41.0 \% / \mathrm{d})$ and abomasum $(56.1 \% / \mathrm{d})$ to small intestine $(87.5 \% / \mathrm{d})$, and then declined significantly $(P<0.05)$ towards the caecum $(45.2 \% / \mathrm{d})$ and the colon $(38.4 \% / \mathrm{d})$. No significant differences were observed between FSR in the duodenum, jejunum or ileum $(P>0.05)$.

4. FGR ranged from $2.6 \% / \mathrm{d}$ in the oesophagus to $8.7 \% / \mathrm{d}$ in the omasum. The ratio, FGR:FSR, which reflected the efficiency of protein deposition, was at a maximum in the stomachs and caecum and at a minimum in the small intestine.

5. The relative contribution of the oesophagus, stomachs, small intestine and large intestine to GIT protein synthesis was $1,13,76$ and $10 \%$ respectively. The GIT accounted for approximately $11.5 \%$ of whole-body protein synthesis.

The importance of the contribution of gastrointestinal tissues to whole-body protein synthesis is now well established in rats (McNurlan \& Garlick, 1980; Goldspink et al. 1984). Fractional synthesis rates (FSR) of tissue protein have been measured in the gastrointestinal tract (GIT) of the ovine fetus (Schaefer \& Krishnamurti, 1984) and newborn (Patureau-Mirand et al. 1986) and growing lambs (Buttery et al. 1977; Arnal et al. 1978; Combe et al. 1979; Davis et al. 1981). Unfortunately all these estimates were obtained after infusion, or injection (Arnal et al. 1978; Combe et al. 1979), of tracer doses of labelled amino acids. This resulted in great differences between the specific radioactivity of the label in the plasma and in the gastrointestinal tissue homogenates (Garlick, 1980). Consequently, in these experiments, the FSR are very different when calculated using the specific radioactivity of the label in both potential precursor pools of protein synthesis. In addition, labelled proteins are released in infused lambs during the experiments, so that proteins exported by cell exfoliation and secretion are not included in the measurements of FSR (James et al. 1971).

Recently, Schaefer et al. (1986) determined tissue protein FSR in sheep during sustained elevation of plasma leucine concentration by intravenous infusion. This procedure prevented significant differences between the specific radioactivity of the label in the plasma and the tissue homogenates, but does not solve the problems that result from labelled protein export and secretion during infusion.

The large-dose technique, i.e. the injection of a large amount of amino acid combined with a tracer dose of the same radiolabelled amino acid, overcomes problems arising both from the determination of the specific activity of the precursor of protein synthesis and from protein export or secretion during the experiments (McNurlan et al. 1979; Garlick et al. 
1980). This technique has been used for measuring protein FSR in the intestine of rats, in a wide variety of conditions, and of chickens (Bryan et al. 1983; Muramatsu et al. 1983). To our knowledge, no attempt has been made in large domestic animals such as lambs.

The aim of the present study was to obtain reliable FSR estimates in the GIT of young preruminant lambs by using the large-dose technique. This was also of interest since there is little information about rates of protein synthesis along the GIT, even in laboratory animals. In addition, we assessed fractional growth rates (FGR) in gastrointestinal tissue proteins for which no information is available.

\section{MATERIALS AND METHODS}

Two experiments were conducted with eighteen male crossbred lambs (Ile de France $x$ Romanov-Limousin). The animals, born in the Sheep Production Laboratory flock (INRA, Theix, France), and weighing $2 \cdot 5-4.0 \mathrm{~kg}$ at birth, were separated from their dams 12-24 host partum. They were then reared in individual metallic cages with mesh floors in a room at $21^{\circ}$, and given only a commercial milk replacer ('Agnodor'; Univor, Paris, France) ad lib. Milk was given by nipple feeders and renewed twice daily. The dry matter intake and the live weight were recorded daily, from the 2 nd day of life to slaughter at 6-9 d of age.

In the first experiment, six lambs received a massive dose of $\mathrm{L}-\left[3,4(n)-{ }^{3} \mathrm{H}\right]$ valine to estimate the FSR of tissue protein in the GIT. Valine was essentially chosen as a label for its high solubility. Moreover, we have previously shown that valine had no effect on plasma insulin or glucagon release in milk-fed lambs (Attaix et al. 1986a).

In the second experiment, all lambs were used to measure the FGR of gastrointestinal tissue proteins.

\section{Experimental procedure}

Expt 1. Protein synthesis experiment. Protein synthesis was measured in vivo after an intravenous injection of a large amount of $\mathrm{L}$-valine, according to the procedure described elsewhere (Attaix et al. 1986a). Jugular catheters were inserted bilaterally into each 5 to 6-d-old lamb. At $2 \mathrm{~d}$ later, the animals received between 10.00 and 11.00 hours, a single intravenous injection of unlabelled L-valine ( $17.1 \mathrm{mmol} / 5 \mathrm{~kg}$ body-weight) combined with $\mathrm{L}-\left[3,4(n)-{ }^{3} \mathrm{H}\right]$ valine $(25-50 \mathrm{Ci} / \mathrm{mmol}$; Amersham International plc, Amersham, Bucks) to give $95 \mu \mathrm{Ci}$ and $0.45 \mathrm{mmol} / \mathrm{ml}$ saline ( $9 \mathrm{~g}$ sodium chloride $/ 1$ ). Blood samples were regularly collected until slaughter, centrifuged and plasma isolated. Pairs of lambs were anaesthetized with sodium pentobarbitone to prevent cell sloughing in the GIT (Attaix et al. 1984), and bled by severing the vessels of the neck 5,13 and 30 min after the injections. The GIT was quickly removed and whole or representative parts of the oesophagus, reticulo-rumen, omasum, abomasum, abomasal mucosa and musculosa, small intestine (duodenum: $150 \mathrm{~mm}$ long from the pylorus; jejunum : $500 \mathrm{~mm}$ long, $1.35 \mathrm{~m}$ beyond the pylorus; ileum: $500 \mathrm{~mm}$ long, $1 \mathrm{~m}$ above the ileo-caecal valve), caecum and colon (sigmoid colon) were rinsed with ice-cold saline. Abomasal mucosa and musculosa were easily separated by means of a surgical blade. Tissue samples were frozen in liquid nitrogen within an average $7 \mathrm{~min}$ period following slaughter, and were stored at $-15^{\circ}$ until analysis.

Plasma $(0.5 \mathrm{ml})$ and tissue samples $(2-16 \mathrm{~g})$ were homogenized with 8 vol. ice-cold trichloroacetic acid (100 g/1; TCA). The protein precipitates were collected by centrifugation (12100 and $5600 \mathrm{~g}$ for the plasma and tissues respectively) for $10 \mathrm{~min}$, then resuspended in TCA. The homogenization was repeated four times and the four supernatant fractions were mixed. The TCA was removed from supernatant fractions by anion-exchange chromatography (Dowex 2-X8; 20-50 mesh). The hydrochloric acid in soluble fractions was then evaporated and the free amino acids resuspended in $0 \cdot 2 \mathrm{M}$-lithium citrate buffer, 
pH 2-2. Portions $(2.5 \mathrm{ml})$ were chromatographed on an amino acid analyser. Amino acids were separated on Aminex A-9 resin (Bio-Rad). To determine the specific radioactivity of free $\mathrm{L}-\left[3,4(n)-{ }^{3} \mathrm{H}\right]$ valine, the column eluate was diverted to liquid scintillation counting $(60 \%)$ and to ninhydrin reaction $(40 \%)$ by a stream splitter (Model ES; Radiomatic Instruments and Chemical Co., Florida, USA) controlling a three-way solenoide valve (Model 1.85.900; General Valve Corporation, New Jersey, USA) within a $5 \mathrm{~s}$ time cycle. Splitting reproducibility was $\pm 0.5 \%$. The radioactivity was measured in a liquid-scintillation spectrometer (Flo-One D/R; Radiomatic Instruments and Chemical Co.), using Pico-Fluor 30 scintillation cocktail (Packard Instrument Co., Illinois, USA). Efficiency counting $(18 \%)$ was calibrated with chromatographed $\mathbf{L}-\left[3,4(n)-{ }^{3} \mathrm{H}\right]$ valine standards in $0 \cdot 2$ M-lithium citrate buffer, $\mathrm{pH} 2 \cdot 2$.

The protein precipitates were delipidated, then dried and pulverized to a powder as previously described (Attaix et al. 1986a). Duplicate portions of protein precipitates (40$50 \mathrm{mg}$ ) were hydrolysed at $60^{\circ}$, in the presence of $0.1 \mathrm{ml}$ water, with $1 \mathrm{ml}$ Soluene- 350 (Packard Instruments Co.) in liquid-scintillation vials. The radioactivity was measured, using $10 \mathrm{ml}$ of a toluene-based scintillation cocktail (Glass \& Woods, 1971) added to the hydrolysates, with a Packard $460 \mathrm{CD}$ spectrometer. Counting efficiency (15-25\%) was determined by external-standard channel ratio. No sample had less than 800 counts $/ \mathrm{min}$, $5 \mathrm{~min}$ after $\left[{ }^{3} \mathrm{H}\right]$ valine injection. Protein pellets were analysed for $\mathrm{N}$ in duplicate, by a Kjeldahl procedure. Tissue crude protein content was calculated as $\mathbf{N} \times 6.25$. The valine content of mixed tissue protein was obtained in duplicate portions $(200 \mathrm{mg})$ of pooled protein precipitates. These pellets were hydrolysed for $48 \mathrm{~h}$ at $110^{\circ}$ in $5 \cdot 5 \mathrm{M}-\mathrm{HCl}$, with norleucine added as an internal standard. The $\mathrm{HCl}$ was eliminated by evaporation and the free amino acids resuspended in $0.2 \mathrm{M}$-sodium citrate buffer, $\mathrm{pH} 2 \cdot 2$, for analysis on an automatic amino acid analyser. The specific radioactivity of protein-bound valine (disintegrations $/ \mathrm{min}(\mathrm{dpm})$ per $\mu \mathrm{mol} ; \mathrm{SB})$ was determined from the specific activity of protein $(\mathrm{dpm} / \mathrm{mg}$ protein) and the valine content of mixed tissue protein. This approximation was thought to be valid, since we verified that $98 \%$ of the radioactivity was valine-bound in jejunum protein hydrolysates of lambs killed 30 min post injection.

An estimate of FSR $(\% / d)$ of tissue protein was calculated as the slope of the linear regression of SB $(t) v$. (SA $\times t)$ by using the following equation (Attaix et al. 1986a):

$$
100 \times \operatorname{SB}(t)=\mathrm{FSR}(\mathrm{SA} \times t)+100 \times \mathrm{SB}\left(t_{\mathbf{0}}\right),
$$

where $t$ is the incorporation time (d), and SA is the mean specific radioactivity of free valine either in plasma or in tissue homogenates between $t_{0}$ and $t$. Individual values of SA were calculated according to Garlick et al. (1980). No allowance was made for the time elapsed between killing the lambs and freezing the tissue samples in liquid $\mathrm{N}_{2}$, as previously discussed (Attaix et al. 1986a).

Expt 2. FGR estimations. The remaining twelve 6- to 9-d-old lambs were killed. The digestive tract was rapidly excised and the different gastrointestinal tissues were separated. All samples were rinsed with ice-cold saline, blotted and weighed. The same procedures were conducted as those used for the lambs in Expt 1, allowance being made for the tissue samples that had been removed for measuring protein synthesis. As for lambs used in Expt 1, tissue protein content was obtained after homogenization of tissue samples in TCA and analysis for $\mathrm{N}$ content of lipid-free protein precipitates. The amount of tissue protein gained per $\mathrm{kg}$ body-weight gained was calculated for each lamb used in Expt 1 by linear regression of total tissue protein mass $v$. the empty body-weight of the other seventeen lambs, according to a procedure described by MacDonald \& Swick (1981). Empty bodyweight was calculated as $96 \%$ live weight in the 1-week-old lamb (Bénévent, 1971). Using the empty body-weight growth rate of each lamb, the tissue protein gained per $d$ was 
Table 1. Expts 1 and 2. Live weight $(\mathrm{kg})$, food intake ( $\mathrm{g}$ dry matter/d), growth rate $(\mathrm{g} / \mathrm{d})$ and weight $(\mathrm{g})$ of gastrointestinal tissues in preruminant lambs

(Mean values with their standard errors)

\begin{tabular}{|c|c|c|c|c|c|c|c|c|c|c|c|}
\hline \multirow[b]{3}{*}{ Expt no. } & \multirow[b]{3}{*}{$n$} & \multirow{2}{*}{\multicolumn{2}{|c|}{$\begin{array}{c}\text { Live wt } \\
\text { (kg) }\end{array}$}} & \multirow{2}{*}{\multicolumn{2}{|c|}{$\begin{array}{c}\text { Growth rate* } \\
\qquad(\mathrm{g} / \mathrm{d})\end{array}$}} & \multirow{2}{*}{\multicolumn{2}{|c|}{$\begin{array}{c}\text { Dry-matter } \\
\text { intake* } \\
(\mathrm{g} / \mathrm{d})\end{array}$}} & \multirow[b]{3}{*}{ Oesophagus } & \multicolumn{2}{|c|}{$\mathrm{Wt}(\mathrm{g})$} & \multirow{3}{*}{$\begin{array}{c}\text { Large } \\
\text { intestine }\end{array}$} \\
\hline & & & & & & & & & & Small & \\
\hline & & Mean & $\mathrm{SE}$ & Mean & SE & Mean & $\mathrm{SE}$ & & Stomachs & intestine & \\
\hline 1 & 6 & $4 \cdot 5$ & 0.2 & 273 & 14 & 189 & 10 & $5 \cdot 3$ & $55 \cdot 2$ & $127 \cdot 1$ & $40 \cdot 6$ \\
\hline 2 & $12 \dagger$ & $4 \cdot 6$ & 0.2 & 253 & 16 & 203 & 12 & 46 & $54 \cdot 1$ & 135.8 & $42 \cdot 8$ \\
\hline
\end{tabular}

* From $2 \mathrm{~d}$ of age to slaughter (7-8 d in Expt 1 and 6-9 d in Expt 2).

$\dagger$ Excluding animals used in Expt 1 , since all lambs were used for fractional growth rate determinations in Expt 2. For details, see p. 161 .

calculated. FGR was then derived from the daily change in tissue protein amount divided by the tissue protein mass present at that time.

\section{Statistical analysis}

The standard errors for slopes and intercepts of regression lines were computed according to Sokal \& Rohlf (1969). For the comparison of FSR in Expt 1, the significance of differences between the slopes of best-fit were assessed according to Snedecor \& Cochran (1971). Bartlett's test of homogeneity of variances (Sokal \& Rohlf, 1969) revealed that heterogeneity was evident for FGR. FGR were therefore subjected to the Kruskal-Wallis test (Sokal \& Rohlf, 1969) and mean values were compared using the Mann-Whitney U test (Mann \& Whitney, 1947).

\section{RESULTS}

All animals were healthy and presented no signs of digestive disorders. The mean growth rate and dry matter intake of lambs used in the two experiments (Table 1) were in the range of values obtained in lambs of the same genotype and bred in similar conditions (Villette \& Theriez, 1981).

SA in the plasma and in tissue homogenates declined very slowly and not significantly $(P>0.05)$ between 5 and 30 min following the injection of the large amount of $\mathrm{L}-[3,4(n)-$ ${ }^{3} \mathrm{H}$ ] valine (Table 2 ). Only slight differences were obtained between lambs. In the plasma, SA for the six lambs was 403140 (SE 7467) $\mathrm{dpm} / \mu \mathrm{mol}, 5 \mathrm{~min}$ post-injection. The SA ratios, tissue homogenate: plasma, were always very high and exceeded 0.78 in any gastrointestinal tissue.

The evolution of SB was linear with respect to time (Table 2). Extrapolation of the values to zero time in calculated regression lines of SB $v$. time generally showed positive intercepts, although they were never significantly different from the origin $(P>0.05)$, except in the oesophagus and the reticulo-rumen.

No significant differences were observed between FSR calculated by using the specific activity of free valine either in the plasma $\left(\mathrm{FSR}_{\text {Minimum }}\left(\mathrm{FSR}_{\mathrm{Min}}\right)\right)$ or in tissue homogenates $\left(\right.$ FSR $_{\text {Maximum }}\left(\right.$ FSR $\left._{\text {Max }}\right)$ ) (Table 3). The highest values for FSR were observed in the small intestine and the abomasal mucosa, and the lowest in the oesophagus. The FSR increased gradually and significantly $(P<0.05)$ from the oesophagus towards the small intestine and then decreased significantly $(P<0.05)$ from the small intestine towards the rectum. 
Table 2. Regression equations relating free $(S A)$ or protein-bound $(S B)\left[{ }^{3} H\right]$ valine specific radioactivity (disintegrations/min per $\mu \mathrm{mol} ; y$ ) in the plasma and gastrointestinal tissues of lambs to time after valine injection ( $\min ; x): y=a+b x$

(Mean values with their standard errors for six lambs)

\begin{tabular}{|c|c|c|c|c|c|c|c|c|}
\hline \multirow[b]{4}{*}{ Tissue } & \multicolumn{8}{|c|}{ Linear coefficient } \\
\hline & \multicolumn{4}{|c|}{ SA } & \multicolumn{4}{|c|}{ SB } \\
\hline & \multicolumn{2}{|c|}{$a$} & \multicolumn{2}{|c|}{$b$} & \multicolumn{2}{|c|}{$a$} & \multicolumn{2}{|c|}{$b$} \\
\hline & Mean & $\mathrm{SE}$ & Mean & $\mathrm{SE}$ & Mean & $\mathrm{SE}$ & Mean & SE \\
\hline Plasma & 405044 & 6062 & $-517^{\mathrm{ss}}$ & 392 & - & - & - & - \\
\hline Oesophagus & 335200 & 27124 & $348^{\mathrm{ss}}$ & 1420 & $295^{*}$ & 22 & 65 & 1 \\
\hline Reticulo-rumen & 346874 & 8115 & $-426^{\mathrm{Ns}}$ & 425 & $367^{*}$ & 101 & 72 & 5 \\
\hline Omasum & 352445 & 14543 & $-701^{\mathrm{Ns}}$ & 762 & $200^{\mathrm{xa}}$ & 119 & 100 & 6 \\
\hline Abomasum & 353526 & 11493 & $-573^{\mathrm{ss}}$ & 602 & $120^{\mathrm{Ne}}$ & 189 & 136 & 10 \\
\hline Abomasal mucosa & 350783 & 14394 & $-1314^{\mathrm{Ns}}$ & 753 & $-16^{\mathrm{ng}}$ & 210 & 169 & 11 \\
\hline Abomasal musculosa & 353098 & 14457 & $-798^{\mathrm{xx}}$ & 757 & $64^{\mathrm{ws}}$ & 114 & 94 & 6 \\
\hline Duodenum & 370286 & 12639 & $-1149^{\mathrm{ss}}$ & 662 & $179^{\text {ms }}$ & 249 & 214 & 13 \\
\hline Jejunum & 358098 & 21972 & $-1675^{\mathrm{ks}}$ & 1410 & $235^{\mathrm{Ns}}$ & 415 & 208 & 22 \\
\hline Ileum & 365983 & 14859 & $-1234^{\mathrm{ss}}$ & 778 & $77^{\mathrm{ss}}$ & 249 & 206 & 13 \\
\hline Caecum & 359605 & 12989 & $-804^{\mathrm{ss}}$ & 680 & $159^{\mathrm{ms}}$ & 274 & 110 & 14 \\
\hline Colon & 362370 & 14255 & $-848^{\mathrm{ss}}$ & 746 & $228^{\mathrm{ws}}$ & 177 & 94 & 9 \\
\hline
\end{tabular}

NS, not significantly different from zero.

* Significantly different from zero $(P<0.05)$.

Tissue protein FGR was low in the oesophagus and the colon and high in the omasum and caecum. The reticulo-rumen, abomasum and small intestine occupied an intermediate position (Table 3). The ratio, FGR:FSR, which reflected the efficiency of protein deposition (Table 4), was higher in the stomachs and caecum than in the oesophagus, the colon and the small intestine.

The absolute rates of protein synthesis and deposition $(\mathrm{g} / \mathrm{d})$ were calculated by multiplying tissue protein content by FSR $_{\mathrm{Max}}$ and FGR respectively (Table 4). The stomachs and the large intestine, which accounted for 20.3 and $16.6 \%$ of the GIT protein mass respectively, synthesized only 13.2 and $9.6 \%$ of the protein synthesized in the GIT (Table 5). On the other hand, the contribution of the small intestine $(60-5 \%$ of the GIT protein mass) to GIT protein synthesis amounted to $76 \cdot 2 \%$.

An estimate of whole-body protein synthesis was calculated as the sum of the absolute rates of protein synthesis in the GIT, the liver and the exsanguinated and eviscerated wholebody, and was found to be 146.4 (SE 5.7) $\mathrm{g} / \mathrm{d}$ in the lambs used in Expt 1. The absolute rates of protein synthesis in liver and in the eviscerated whole-body were obtained by multiplying FSR $_{\text {Max }}$ in these tissues $(115.0$ and $19.6 \% / \mathrm{d}$, respectively) (Attaix et al. $1986 \mathrm{~b}$ ) by their corresponding protein mass (14.9 (SE 5.7) and 572.7 (SE 19.8) g respectively) (D. Attaix and A. Manghebati, unpublished results). The contribution of the GIT to whole-body protein synthesis was estimated to be $11.5 \%$ (Table 5). A similar estimation $(10.7 \%)$ was obtained when FSR $_{\text {Min }}$ were used for this calculation. The small intestine exerted a significant contribution to whole-body protein synthesis $(8.8 \%)$. By contrast, the relative contributions of the oesophagus $(0.1 \%)$, the stomachs $(1.5 \%)$ and the large intestine $(1 \cdot 1 \%)$ to wholebody protein synthesis were very low. 
Table 3. Tissue protein fractional synthesis rates (FSR) and fractional growth rates (FGR) in the gastrointestinal tract of the preruminant lamb

(Mean values with their standard errors for six lambs)

\begin{tabular}{|c|c|c|c|c|c|c|}
\hline \multirow[b]{3}{*}{ Tissue } & \multicolumn{4}{|c|}{$\operatorname{FSR}(\% / \mathrm{d})$} & & \\
\hline & \multicolumn{2}{|c|}{ Min* } & \multicolumn{2}{|c|}{ Max* } & \multicolumn{2}{|c|}{$\operatorname{FGR}(\% / d)$} \\
\hline & Mean & SE & Mean & $\mathrm{SE}$ & Mean & $\mathrm{SE}$ \\
\hline Oesophagus & $23 \cdot 5^{\mathrm{a}}$ & $0 \cdot 1$ & $26 \cdot 5^{\mathrm{a}}$ & 1.8 & $2 \cdot 6^{\mathrm{a}}$ & $0 \cdot 1$ \\
\hline Reticulo-rumen & $26 \cdot 2^{a b}$ & $1 \cdot 8$ & $30 \cdot 1^{\mathrm{ab}}$ & $2 \cdot 2$ & $4 \cdot 0^{b}$ & $0 \cdot 1$ \\
\hline Omasum & $36 \cdot 3^{\mathrm{c}}$ & $2 \cdot 2$ & $41 \cdot 0^{\mathrm{c}}$ & $3 \cdot 0$ & $8 \cdot 7^{\mathrm{e}}$ & $0 \cdot 4$ \\
\hline Abomasum & $49 \cdot 5^{\text {de }}$ & 3.7 & $56 \cdot 1^{d}$ & $3 \cdot 8$ & $6 \cdot 1^{\text {de }}$ & $0 \cdot 4$ \\
\hline Abomasal mucosa & $61 \cdot 4^{\text {ef }}$ & $4 \cdot 1$ & $74 \cdot 1^{\mathrm{e}}$ & $4 \cdot 3$ & + & +4 \\
\hline Abomasal musculosa & $34 \cdot 2^{c}$ & $2 \cdot 4$ & $39 \cdot 1^{*}$ & $1 \cdot 7$ & - & - \\
\hline Duodenum & $77 \cdot 9^{8}$ & $4 \cdot 6$ & $86 \cdot 0^{\mathrm{e}}$ & $6 \cdot 0$ & - & - \\
\hline Jejunum & $75 \cdot 8^{\mathrm{tg}}$ & 7.9 & $92 \cdot 5^{\mathrm{e}}$ & $13-3$ & - & - \\
\hline Ileum & $74 \cdot 6^{\mathrm{gg}}$ & $5 \cdot 0$ & $84 \cdot 1^{\mathrm{e}}$ & 6.6 & - & - \\
\hline Small intestine $\dagger$ & $76 \cdot 1$ & - & $87 \cdot 5$ & - & $6 \cdot 1^{\mathrm{e}}$ & $0 \cdot 3$ \\
\hline Caecum & $40 \cdot 0^{\text {cd }}$ & $5 \cdot 3$ & $45 \cdot 2^{\text {cd }}$ & $5 \cdot 4$ & $7.6^{\mathrm{ed}}$ & 0.6 \\
\hline Colon & $34 \cdot 1^{b c}$ & 3.8 & $38 \cdot 4^{\mathrm{be}}$ & 3.5 & $3 \cdot 0^{\mathrm{ab}}$ & 0.4 \\
\hline
\end{tabular}

a-g, Values within the same column not sharing a common superscript letter were significantly different $(P<0.05)$.

${ }^{*} \mathrm{FSR}_{\mathrm{Min}}$ and $\mathrm{FSR}_{\mathrm{Max}}$ were not significantly different in any tissue $(P>0.05)$.

$\dagger$ Mean of duodenum, jejunum and ileum FSR.

Min, Max, minimum and maximum estimates of FSR obtained using the specific radioactivity of free valine in the plasma and the tissues homogenates respectively.

\section{DISCUSSION}

\section{Measurements of protein synthesis}

In the present study, FSR were obtained by using the large-dose technique (McNurlan et al. 1979 ; Garlick et al. 1980). It is, however, very important to prove that the large amount of amino acid does not affect FSR measurements. We have recently reported that FSR in the jejunum, liver and skeletal muscle were not significantly altered when 1-week-old lambs received a massive amount of $17 \cdot 1 \mathrm{mmol} \mathrm{L}-\left[3,4(\mathrm{n})-{ }^{3} \mathrm{H}\right]$ valine $/ 5 \mathrm{~kg}$ body-weight compared with a lower massive amount of $12.8 \mathrm{mmol} \mathrm{L}-\left[3,4(n)-{ }^{3} \mathrm{H}\right]$ valine $/ 5 \mathrm{~kg}$ body-weight (Attaix et al. 1986 a). Therefore, it seems very unlikely that the large amount of valine that we used had any effect on FSR determinations.

Since the SA ratios, tissue homogenate:plasma, were very high, FSR calculated by using the SA in both potential precursor pools were not significantly different (Table 3). This contrasted with findings obtained in gastrointestinal tissues of lambs, either by using the constant-infusion technique (Davis et al. 1981; Schaefer \& Krishnamurti, 1984) or by a pulse injection of $\mathrm{L}-\left[\mathrm{U}-{ }^{14} \mathrm{C}\right]$ lysine (Arnal et al. 1983), and demonstrated the advantages of a massive injection of amino acid. However, there is also evidence that lumen amino acids are preferentially utilized for protein synthesis in the small intestinal mucosa (Hirschfield \& Kern, 1969; Alpers, 1972). To our knowledge, it has not been verified in large-dose experiments that the specific radioactivity of the label in the lumen amino acid pool approached the specific radioactivity of the precursor in the mucosal tissue homogenate. 


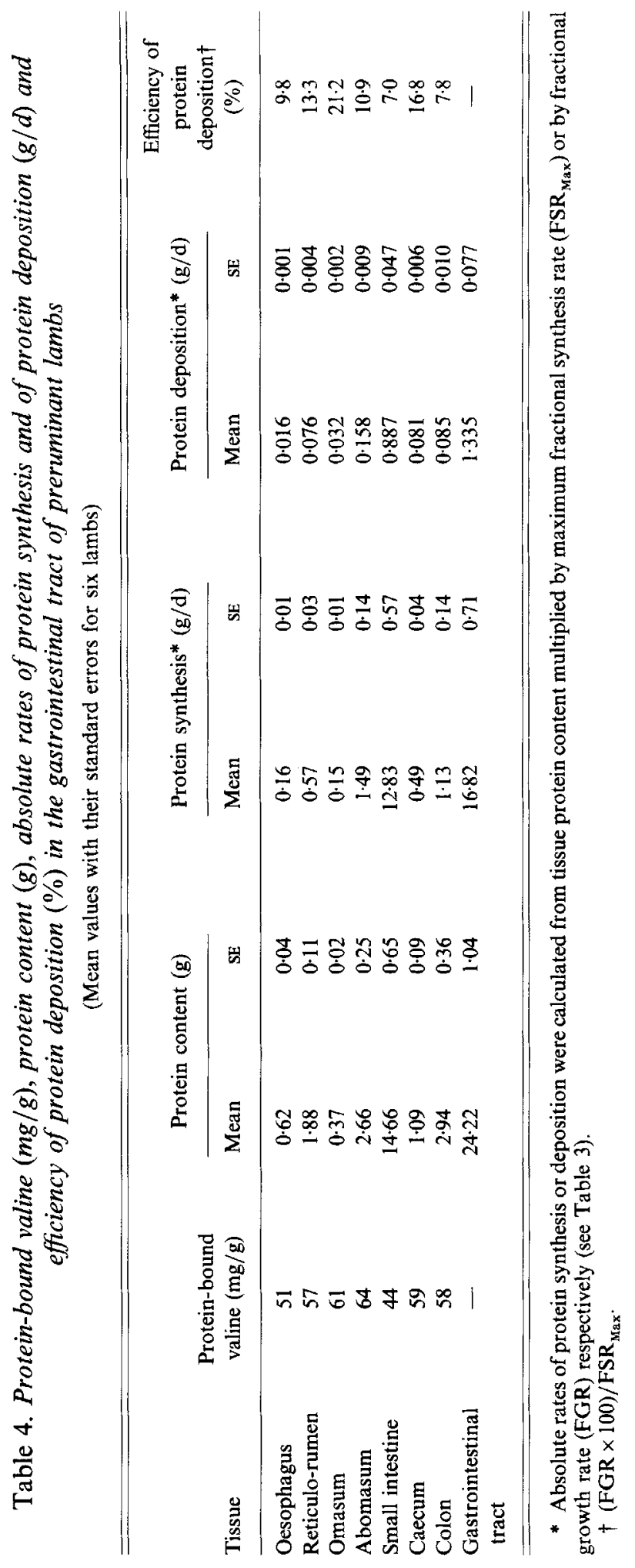


Table 5. Percentage contributions of gastrointestinal tissues to gastrointestinal tract (GIT) protein mass (GITPM) or synthesis (GITPS), and to whole-body protein mass (WBPM) or synthesis (WBPS)

\begin{tabular}{lcccc}
\hline \hline Tissue & GITPM & GITPS* & WBPM ${ }^{\dagger}$ & WBPS $\ddagger$ \\
\hline Oesophagus & $2 \cdot 6$ & $1 \cdot 0$ & $0 \cdot 1$ & $0 \cdot 1$ \\
Reticulo-rumen & $7 \cdot 8$ & $3 \cdot 4$ & $0 \cdot 3$ & $0 \cdot 4$ \\
Omasum & $1 \cdot 5$ & $0 \cdot 9$ & $0 \cdot 1$ & $0 \cdot 1$ \\
Abomasum & $11 \cdot 0$ & $8 \cdot 9$ & $0 \cdot 4$ & $1 \cdot 0$ \\
Small intestine & $60 \cdot 5$ & $76 \cdot 2$ & $2 \cdot 4$ & $8 \cdot 8$ \\
Caecum & $4 \cdot 5$ & $2 \cdot 9$ & $0 \cdot 2$ & $0 \cdot 3$ \\
Colon & $12 \cdot 1$ & $6 \cdot 7$ & $0 \cdot 5$ & 0.8 \\
Gastrointestinal tract & 100 & 100 & $4 \cdot 0$ & $11 \cdot 5$ \\
\hline
\end{tabular}

* Contributions of gastrointestinal tissues to GITPS or WBPS were calculated from absolute synthesis rates (see Table 4).

+611.8 (SE 21.6) g, includes exsanguinated and eviscerated whole-body, liver and GIT protein content. For details, see p. 163 .

$\ddagger 146.4$ (SE $5 \cdot 7) \mathrm{g} / \mathrm{d}$, sum of absolute protein synthesis rates (maximum fractional synthesis rate $\times$ protein content) in the exsanguinated and eviscerated whole-body, liver and GIT. For details, see p. 163.

\section{Tissue protein FSR}

Comparison of our findings and of gastrointestinal tissue protein FSR reported by others in lambs or sheep is particularly difficult and could be misleading for several reasons. First, these FSR crucially depend on the choice of the precursor pool of protein synthesis. Second, in infused animals, the proteins exported by secretion or cell exfoliation are not taken into account in FSR measurements. The same problems are encountered with the recent procedure proposed by Schaefer et al. (1986), when the concentration of the radiolabelled amino acid is sustained by simultaneous infusion of the same unlabelled amino acid. Therefore, the large-dose technique gives higher estimates of FSR in the GIT than the continuous-infusion technique (McNurlan et al. 1979; Garlick, 1980). Finally, all the published studies differ in the live weight of lambs and methodology used, or both. Consequently, tissue protein FSR varies greatly between experiments (Davis et al. 1981). However, we observed among the gastrointestinal tissues the highest values for FSR in the small intestine (Table 3), as previously reported by Buttery et al. (1977) in ruminant lambs and by Schaefer \& Krishnamurti (1984) in the ovine fetus.

Comparison of our findings with results in other species is also difficult, since information for sucking animals is poorly documented. Our estimates for FSR in the duodenum, jejunum or ileum $(84.1-92.5 \% / \mathrm{d})$ compared favourably with the value of $100 \% / \mathrm{d}$ reported for the intestine of immature rats by using a large amount of $\left[{ }^{3} \mathrm{H}\right]$ phenylalanine (Reeds et al. 1982). Compared with results obtained in large-dose experiments in weaned rats, our estimates in the small and large intestines $(87.5-38.4 \% / \mathrm{d})$ are slightly lower than the values reported in 21 -d-old animals $(97.5-57.8 \% / \mathrm{d})$ by Goldspink et al. (1984) and in $100 \mathrm{~g}$ rats $(103 \cdot 4-62 \cdot 1 \% / d)$ by McNurlan \& Garlick (1980). In the stomach of the $100 \mathrm{~g}$ rat, McNurlan \& Garlick (1980) reported a FSR of $74 \% / \mathrm{d}$ which is also higher than our estimate in the abomasum $(56 \cdot 1 \% / \mathrm{d})$.

The positive gradient of FSR from oesophagus to small intestine may correlate with the gradient of metabolic activity in the GIT of preruminant animals. The young preruminant is physiologically a simple-stomached animal. The majority of liquid feed bypasses the reticulo-rumen by means of the oesophageal groove, and goes directly through the omasum to the abomasum (Church, 1969). The rumen mucosa exhibits only small and undeveloped 
papillae in milk-fed young ruminants (Warner \& Flatt, 1965; Stobo et al. 1966; Church, 1969). Therefore, a rather low estimate of FSR could be expected in the reticulo-rumen (Table 3). The significantly higher FSR of the abomasum $(56.1 \% / \mathrm{d})$ compared with the omasum $(41.0 \% / \mathrm{d})$ probably reflected the synthesis and secretion of digestive enzymes which do not occur in the forestomach. This was supported by the estimate of FSR that we measured in the abomasal mucosa $(74.1 \% / \mathrm{d})$ compared with the abomasal musculosa $(39-1 \% / d)$. The latter value was in agreement with the oesophageal smooth muscle FSR $(41.6 \% / d)$ reported by Lewis et al. (1984) in the 21 -d-old rat. However, our estimate in the whole oesophagus was very different $(26.5 \% / \mathrm{d})$ and in the same range as the $22.9 \% / \mathrm{d}$ value determined in the skeletal $\mathrm{M}$. tensor fasciae latae of 1-week-old lambs (Attaix et al. $1986 a$ ). In the rat, the lower two-thirds of the oesophagus contains only smooth muscle, and the $41.6 \% / \mathrm{d}$ value reported by Lewis et al. (1984) referred only to this portion. By contrast, the oesophagus of the sheep contains essentially striated muscle (Comline et al. 1968). Higher FSR in the smooth muscle than in striated muscles have been reported throughout the development of the rat (Lewis et al. 1984).

Cell turnover accounts for a significant loss of protein in the gut and therefore could explain the high rates of protein synthesis in the GIT (Alpers \& Kinzie, 1973; McNurlan et al. 1979). It is noteworthy that the pattern for FSR that we observed, increasing from oesophagus to small intestine and then decreasing towards the rectum, corresponded to a similar pattern for both labelling and mitotic indexes in the GIT of the rat (Sakata \& Yajima, 1984). However, these indexes represent a state and do not measure the rate of cell production.

Measurements of cell production rate have not been performed along the GIT of preruminant animals. We have measured an epithelial cell transit time of approximately 50 , 91 and $94 \mathrm{~h}$ in the duodenum, jejunum and ileum respectively, of lambs of identical genotype and reared in similar conditions as those of the present experiment (Attaix et al. 1984). By contrast, our estimates of FSR were not significantly different from duodenum to ileum (Table 3). However, it may be argued that differences in cell transit times did not necessarily imply differences in cell production per unit of small intestine surface. Southon et al. $(1985 \mathrm{~b})$ found similarly no relation between the rates of cell production and protein synthesis in mucosal scrapes in zinc-deficient rats. This contrasted with a previous report of the same group that a reduction in the FSR was associated with a decreased mucosal cell proliferation in rats given a semi-synthetic diet when compared with pellet-fed animals (Southon et al. 1985a). These discrepancies probably resulted from the large-dose technique used for measuring protein synthesis which offers no means of studying the partition of protein synthesis between intracellular turnover, cell secretion and cell renewal. Therefore, the decrease in FSR from the small intestine to the caecum and colon cannot be interpreted only in terms of a reduced cell turnover, as previously suggested in the rat (McNurlan \& Garlick, 1980). Although the hypothesis of reduced cell-production rate along the intestines cannot be excluded, it is noteworthy that the rat large intestine exhibited a lower ribosomal capacity than the small intestine 3-105 weeks after birth (Goldspink et al. 1984).

\section{Contribution of the GIT to whole-body protein synthesis}

As for FSR, comparisons of our estimates with other published values for lambs are difficult to make due to methodological considerations and stage of development of the animals used. However, our estimate of $11.5 \%$ for the contribution of the GIT to whole-body protein synthesis was close to the $13.9 \%$ value obtained by using the constant-infusion technique in the ovine fetus (Schaefer \& Krishnamurti, 1984). By contrast, our estimate was lower than the estimates made in growing, ruminant lambs (18-34\%) by Davis et al. (1981), and in cattle $(32 \cdot 1-45 \cdot 9 \%)$ by Lobley et al. (1980). However, the contribution of the GIT 
to protein synthesis, calculated as the sum of muscles, skin, liver and GIT protein synthesis, has been reported to increase significantly in lambs, between 1 and 16 weeks of age, especially after weaning (Combe et al. 1979). The development of the ruminant stomach and the importance of dietary fibre in the diet of ruminants could explain this increase. In a recent report Southon et al. (1985a) have shown that giving rats a commercial pelleted diet led to a significant increase in small intestinal FSR compared with that of rats fed on a fibre-free, semi-synthetic diet. On the other hand, compared with the estimates obtained with large-dose experiments in rodents, the contribution of the small and large intestine to whole-body protein synthesis $(8 \cdot 8$ and $1.1 \%$ respectively) appeared, to a lesser extent, to be lower than the values reported for the intestines of immature lean Zucker rats $(16.2 \%)$ by Reeds et al. (1982), and by McNurlan \& Garlick (1980) in the $100 \mathrm{~g}$ rat (15.2 and $2.5 \%$ for the small and large intestine respectively). The contribution of the stomachs to whole-body protein synthesis $(1.5 \%)$ was also in close agreement with the $1.1 \%$ value calculated for the $100 \mathrm{~g}$ rat stomach (McNurlan \& Garlick, 1980).

\section{Conclusions}

The large-dose technique appeared suitable to obtain reliable estimates for FSR in the GIT of large domestic animals. The present findings demonstrated that a positive gradient for FSR was observed from the oesophagus to the small intestine; thereafter FSR declined from the small intestine to the rectum. Our results also suggested that both in terms of FSR and contribution of GIT to whole-body protein synthesis, there were only slight differences between the preruminant lamb and the immature rat.

The financial support of the French Ministry of Research and Technology is gratefully acknowledged. The authors would like to thank Mr M. Sallas and A. Selle for animal care, and Mrs E. Aurousseau, F. Barre, O. Bernard, M. C. Valluy and Mr J. Prugnaud for their excellent technical assistance.

\section{REFERENCES}

Alpers, D. H. (1972). Journal of Clinical Investigation 51, 167-173.

Alpers, D. H. \& Kinzie, J. L. (1973). Gastroenterology 64, 471-496.

Arnal, M., Ferrara, M. \& Fauconneau, G. (1978). Proceedings 29th Meeting European Association for Animal Production, Stockholm, Sweden, pp. 1-6.

Arnal, M, Obled, C.\& Attaix, D. (1983). In Protein Metabolism and Nutrition, European Association for Animal Production Publication no. 31, vol. I, pp. I17-136. [M. Amal, R. Pion and D. Bonin, editors]. Paris: INRA Publications.

Attaix, D., Manghebati, A., Grizard, J. \& Arnal, M. (1986a). Biochimica et Biophysica Acta 882, $389-397$.

Attaix, D., Manghebati, A., Grizard, J. \& Arnal, M. (1986b). Diabète et Métabolisme, Paris 12, Abstract 107.

Attaix, D., Meslin, J. C. \& Combe, E. (1984). Nutrition Reports International 29, 689-697.

Bénévent, M. (1971). Annales de Biologie Animale, Biochimie, Biophysique 11, 5-39.

Bryan, L., Buttery, P. J. \& Fisher, C. (1983). In Protein Metabolism and Nutrition, European Association for Animal Production Publication no. 31, vol. II, pp. 53-56 [R. Pion, M. Arnal and D. Bonin, editors]. Paris: INRA Publications.

Buttery, P. J., Beckerton, A. \& Lubock, M. H. (1977). In Protein Metabolism and Nutrition, European Association for Animal Production Publication no. 22, pp. 32-34 [S. Tamminga, editor]. Wageningen: Pudoc.

Church, D. C. (1969). Digestive Physiology and Nutrition of Ruminants, vol. 1, pp. 27-38, pp. 59-84. Corvallis: Oregon State University.

Combe, E., Attaix, D. \& Arnal, M. (1979). Annales de Recherches Vétérinaires 10, 436-439.

Comline, R. S., Silver, I. A. \& Steven, D. H. (1968). In Handbook of Physiology, vol. v, Sect. 6, pp. 2647-267I [C. F. Code, editor]. Baltimore: American Physiological Society.

Davis, S. R., Barry, T. N. \& Hughson, G. A. (1981). British Journal of Nutrition 46, 409 419.

Garlick, P. J. (1980). In Comprehensive Biochemistry, vol. 19B, part I, pp. 77-152 [M. Florkin and E. H. Stotz, editors]. Amsterdam: Elsevier.

Garlick, P. J., McNurlan, M. A. \& Preedy, V. R. (1980). Biochemical Journal 192, 719-723. 
Glass, D. S. \& Woods, T. L. (1971). In Liquid Scintillation Counting, vol. I, pp. 79-95 [A. Dyer, editor]. London: Heyden.

Goldspink, D. F., Lewis, S. E. M. \& Kelly, F. J. (1984). Biochemical Journal 217, 527-534.

Hirschfield, J. S. \& Kern, F. Jr (1969). Journal of Clinical Investigation 48, 1224-1229.

James, W. P. T., Garlick, P. J. \& Millward, D. J. (1971). Gut 12, 495-496.

Lewis, S. E. M., Kelly, F. J. \& Goldspink, D. F. (1984). Biochemical Journal 217, 517-526.

Lobley, G. E., Milne, V., Lovie, J. M. Reeds, P. J. \& Pennie, K. (1980). British Journal of Nutrition 43, 491502 .

MacDonald, M. L. \& Swick, R. W. (1981). Biochemical Journal 194, 811-819.

McNurlan, M. A. \& Garlick, P. J. (1980). Biochemical Journal 186, 381-383.

McNurlan, M. A., Tomkins, A. M. \& Garlick, P. J. (1979). Biochemical Journal 178, $373-379$.

Mann, H. B. \& Whitney, D. R. (1947). Annals of Mathematical Statistics 18, 50-60.

Muramatsu, T., Coates, M. E., Hewitt, D., Salter, D. N. \& Garlick, P. J. (1983). British Journal of Nutrition 49 , 453-462.

Patureau-Mirand, P., Debras, E. \& Prugnaud, J. (1986). Reproduction, Nutrition, Développement 26, $677-682$.

Reeds, P. J., Haggarty, P., Wahle, K. W. J. \& Fletcher, J. M. (1982). Biochemical Journal 204, 393-398.

Sakata, T. \& Yajima, T. (1984). Quarterly Journal of Experimental Physiology 69, 639-648.

Schaefer, A. L., Davis, S. R. \& Hughson, G. A. (1986). British Journal of Nutrition 56, 281-288.

Schaefer, A. L. \& Krishnamurti, C. R. (1984). Growth 48, 309-320.

Snedecor, G. W. \& Cochran, W. G. (1971). Méthodes Statistiques, 6th ed. Paris: Association de Coordination Agricole.

Sokal, R. R. \& Rohlf, F. J. (1969). Biometry. San Fransisco: W. H. Freeman.

Southon, S., Livesey, G., Gee, J. M. \& Johnson, I. T. (1985a). British Journal of Nutrition 53, 87-95.

Southon, S., Livesey, G., Gee, J. M. \& Johnson, I. T. $(1985$ b). British Journal of Nutrition 53, $595-603$.

Stobo, I. J. F., Roy, J. H. B. \& Gaston, H. J. (1966). British Journal of Nutrition 20, $171-188$.

Villette, Y. \& Theriez, M. (1981). Annales de Zootechnie 30, 151-168.

Warner, R. G. \& Flatt, W. P. (1965). In Physiology of Digestion in the Ruminant, pp. 24-38 [R. W. Dougherty, R. S. Allen, W. Burroughs, N. L. Jacobson and A. D. McGilliard, editors]. Washington, DC: Butterworths. 